\title{
Východiska a historické souvislosti procesu plánování v oblasti vod
}

\section{JAKUB ČURDA, JAROSLAV KINKOR}

\author{
Klíčová slova: plánování - Rámcová směrnice o vodách - Povodňová směrnice - Evropská unie
}

\section{SOUHRN}

Plánování v oblasti vod je soustavná koncepční činnost, kterou podle vodního zákona zajištuje stát a která implementuje požadavky Rámcové směrnice o vodách. Hlavním cílem politiky této směrnice je dosažení dobrého stavu vod. Následující text si klade za cíl podat stručný souhrn historických souvislostí i současných východisek procesu plánování v oblasti vod.

\section{ÚVOD}

Dne 22. prosince 2000 nabyla účinnosti Směrnice Evropského parlamentu a Rady 2000/60/ES ze dne 23. řijna 2000, kterou se stanoví rámec pro činnost Evropského společenství v oblasti vodní politiky (dále jen Rámcová směrnice o vodách či RSV). Tato směrnice predstavuje pravděpodobně nejvýznamnější legislativní nástroj $v$ oblasti vodní politiky a je zároveň jednou z nejsložitějších směrnic vytvořených na úrovni Evropské unie (dále jen EU). Príijetí směrnice představovalo významný nový impuls i pro vodohospodářské plánování, které má na území České republiky dlouhou tradici. V souvislosti s přípravou nové české vodohospodářské legislativy, která reagovala na požadavek transpozice této směrnice do českého právního rádu, byl v zákoně č. 254/2001 Sb., o vodách a o změně některých zákonů (vodní zákon) zapracován zcela nový systém vodohospodářského plánování a pro tento systém bylo zavedeno nové označení Plánování v oblasti vod.

\section{PLÁNOVÁNÍ V OBLASTI VOD}

Plánování v oblasti vod je soustavná koncepční činnost, kterou podle vodního zákona zajištujuje stát a která implementuje požadavky Rámcové směrnice o vodách. Hlavním cílem politiky této směrnice je dosažení dobrého stavu vod do roku 2015 s možností prodloužení této Ihůty na maximálně dvě následující aktualizace plánů, které probíhají v šestiletých obdobích (dobrého stavu je tedy nutno dosáhnout do roku 2027, s výjimkou prípadů, kdy prírodní podmínky jsou takové, že stanovených cílů nemůže být v těchto obdobích dosaženo). Hlavní nástroj k dosažení těchto cílů predstavují plány povodí a plány pro zvládání povodňových rizik, resp. jimi stanovený program opatření. Tyto plány jsou významným podkladem pro výkon veřejné správy, zejména pak pro územní plánování a vodoprávní rízení. Pưsobnost ústředního vodoprávního úřadu ve věci sestavování plánů vykonává, podle vodního zákona, Ministerstvo zemědělství a Ministerstvo životního prostredí.
Proces plánování se neobejde bez účinné koordinace širokého spektra zúčastněných subjektů. Za tímto účelem Ministerstvo zemědělství v roce 2003 ustanovilo Komisi pro plánování v oblasti vod a fakticky tím odstartoval proces plánování v České republice.

Za účelem zajištění koordinovaného přístupu při provádění Rámcové směrnice o vodách na úrovni Evropské unie byla uzavřena vzájemná dohoda členských států, Evropské komise a Norska na společné implementační strategii (Common Implementation Strategy, dále jen CIS) pro tuto směrnici, a to již v květnu 2001, tj. jen pět měsíců po vstupu směrnice $v$ platnost. Dalším z důvodů pro ustavení CIS byl mimo jiné i fakt, že řada povodí významných evropských řek pokrývá území hned několika států (např. povodí řeky Dunaje zahrnuje území 14 států) a přes rozdílné administrativní a územní členění je přínosný společný a koordinovaný přístup k ochraně vod, což přispívá k efektivnímu a úspěšnému provádění této směrnice. Především z těchto důvodu bylo do společného procesu zavádění RSV zapojeno kromě členských států EU, kandidátských zemí a zemí EHP i řada nevládních organizací a dalších zúčastněných subjektů.

V rámci organizační struktury CIS byly ustaveny pracovní skupiny, které se zabývají konkrétními dílčími tématy, kdy rídícím orgánem v rámci CIS jsou „Vodní ředitelé", kteří na svých zasedáních schvalují výstupy (např. směrné dokumenty EK (Guidance documents) apod.) z těchto pracovních skupin. Koordinační roli ve struktuře CIS zajišťuje Strategická koordinační skupina (SCG), která koordinuje činnosti pracovních skupin a je podřizená grémiu „Vodních ředitelü“ EU. S ohledem na sdílenou kompetenci ve vodním hospodářství mezi rezorty Ministerstva životního prostředí a Ministerstva zemědělství zastupují ČR dva „Vodní ředitelé“, jakožto zástupci obou rezortů.

Po zavedení Směrnice Evropského parlamentu a Rady 2007/60/ES o vyhodnocování a zvládání povodňových rizik (dále jen Povodňová směrnice) byla do činností CIS zahrnuta také koordinace povodňové ochrany na úrovni EU.

V současné době, podle schváleného plánu prací na období 2016-2018, struktura CIS zahrnuje pět tematických skupin věnujících se problematice ekologického stavu - pracovní skupina ECOSTAT, chemickým látkám ve vodním prostředí - pracovní skupina Chemicals, podzemním vodám - pracovní skupina Groundwater, povodňové ochraně - pracovní skupina Floods a oblasti správy dat a reportingu - pracovní skupina Data and Information Sharing. Hlavním výstupem činnosti pracovních skupin CIS bylo do současnosti vytvorení více než třiceti směrných dokumentů a řady technických dokumentů, které slouží jako podpůrný metodický př́stup, který je však v řadě oblastí potřeba přizpůsobit specifickým podmínkám členských států EU. V neposlední řadě činnosti pracovních skupin přispívají k vzájemné výměně zkušeností z národních úrovní, která přispívá k lepší koordinaci provádění Rámcové směrnice o vodách a Povodňové směrnice. 


\section{PRVNÍ ETAPA PROCESU PLÁNOVÁNÍ V OBLASTI VOD}

První etapa procesu plánování v oblasti vod probíhala do roku 2015. V letech 2004 až 2007 byl zpracován koncepční dokument Plán hlavních povodí České republiky (dále jen PHP). Tento dokument stanovoval dlouhodobou koncepci oblasti vod, integroval záměry a cíle rezortních politik ústředních vodoprávních úřadů, zejména pak Koncepce vodohospodářské politiky Ministerstva zemědělství pro období po vstupu do Evropské unie na léta 2004-2010 a Státní politiky životního prostředí 2004-2010, a stal se základním podkladem pro zpracování plánů oblastí povodí. PHP byl schválen usnesením vlády České republiky ze dne 23. května 2007 Č. 562. Závazná část PHP byla vyhlášena nařízením vlády č. 262/2007 Sb.

$\checkmark$ návaznosti na PHP bylo následně zpracováno osm plánů oblastí povodí, které byly schváleny do 22. prosince 2009 jednotlivými kraji podle jejich územní působnosti. V plánech oblastí povodí jsou uvedena všechna opatření, jež se měla v příslušných povodích přijmout $k$ dosažení dobrého stavu všech vodních útvarů do roku 2015 ve smyslu cílů dobrého ekologického a chemického stavu útvarů povrchových vod a dobrého kvantitativního a chemického stavu útvarů podzemních vod. Vodní zákon stanovil pro 1. cyklus plánů, nad rámec požadavků vyplývajících z Rámcové směrnice o vodách, rovněž cíle v ochraně před povodněmi a dalšími škodlivými účinky vod a cíle pro udržitelné uživání vodních zdrojů zejména pro účely zásobování pitnou vodou. Realizace programů opatření príijatých plány oblastí povodí probíhala od roku 2010 do konce roku 2012.

Součástí požadavků Rámcové směrnice o vodě, které jsou na jednotlivé členské státy kladeny, je také předávání povinných zpráv Evropské komisi, tzv. reporting. Tyto zprávy jsou následně komisí vyhodnocovány a souhrnně zpracovány do tzv. implementačních zpráv, ve kterých Ize nalézt souhrnné informace o pokroku v jednotlivých členských státech, ale také cíleně adresovaná doporučení jednotlivým zemím ke zlepšení provádění identifikovaných požadavků. O príijetí plánů povodí byla tedy v souladu s těmito požadavky v roce 2010 podána zpráva Evropské komisi. V souladu s článkem 15 odst. 3) Rámcové směrnice o vodách byla na konci roku 2012 následně podána Evropské komisi také zpráva o pokroku dosaženém při provádění programu opatření.

Jelikož je ČR řadu let také smluvní stranou řady mezinárodních smluv v oblasti vodního hospodářství, at už na úrovni hraničních vod se sousedními státy ČR, nebo ucelených mezinárodních povodí je nezbytné zajištovat i koordinaci zavádění požadavků výše uvedených směrnic i v mezinárodním kontextu.

$\checkmark$ rámci mezinárodních povodí řek Labe, Odry a Dunaje, do kterých území ČR náleží, byly $v$ průběhu 90. let 20. století postupně ustaveny mezinárodní komise - Mezinárodní komise pro ochranu Labe (MKOL), Mezinárodní komise pro ochranu Odry před znečištěním (MKOOpZ) a Mezinárodní komise pro ochranu Dunaje (MKOD), které se od svého vzniku zaměřují na koordinovanou ochranu vod v měřitku mezinárodních povodí. Po nabytí účinnosti Rámcové směrnice o vodách se naplňování požadavků této směrnice stalo postupně jedním z nosných témat. Vyvrcholení společně koordinované činnosti procesu plánování v oblasti vod představovalo v roce 2009 schválení mezinárodních plánů povodí pro ucelená povodí řek Labe, Odry a Dunaje, včetně určení společných nadregionálních cílů v ochraně vod. Na pořizení těchto mezinárodních plánů povodí se podílela raada národních expertů jednotlivých smluvních stran.

Obecně Ize $v$ tomto kontextu konstatovat, že se nepodařilo v období do konce roku 2012 realizovat všechna plány navržená opatření. Hlavní překážky v realizaci či implementaci opatření spočívaly nejčastěji v obtižném a časově náročném vypořádání komplikovaných majetkoprávních vztahů. Další významnou překážkou bylo rovněž nedostatečné rozpracování a projektová připravenost jednotlivých akcí. Tento fakt byl významně spojen se skutečností, že drobné vodní toky (na kterých byla v této oblasti povodí převážná část opatření k zajištění odpovídajících hydromorfologických podmínek) přešly z gesce zrušené Zemědělské vodohospodářské správy, která byla do té doby správcem drobných vodních toků, na státní podniky Povodí, přičemž mnoho projektů nebylo do doby transformace zásadně projektově rozpracováno.

\section{DRUHÁ ETAPA PROCESU PLÁNOVÁNÍ V OBLASTI VOD}

V reakci na připomínky Evropské komise (tzv. infringement) k neúplně provedené transpozici Rámcové směrnice o vodách došlo v roce 2010 k novelizaci vodního zákona zákonem č. 150/2010 Sb., který rovněž obsahoval transpozici směrnic 2006/118/ES o ochraně podzemních vod před znečištěním a zhoršováním stavu a směrnice 2008/105/ES o normách environmentální kvality v oblasti vodní politiky. Pro druhou etapu procesu tak byla stanovena nová struktura zpracování aktualizace plánů povodí. Plány povodí se ve druhé etapě pořizovaly ve třech úrovních:

- pro mezinárodní oblasti povodí (dále jen mezinárodní plány povodí),

- pro části mezinárodních oblastí povodí na území České republiky (dále jen národní plány povodí),

- pro díĺí povodí.

V geografických a hydrografických podmínkách ČR jsou pořizovány tři národní plány povodí (dále jen NPP) a deset plánů dílčích povodí (dále jen PDP).

Další významnou součástí plánování v oblasti vod jsou od roku 2010 i náležitosti implementace Směrnice Evropského parlamentu a Rady 2007/60/ES o vyhodnocování a zvládání povodňových rizik. Účelem této směrnice je stanovit rámec pro vyhodnocování a zvládání povodňových rizik s cílem snížit nepříznivé účinky na lidské zdraví, životní prostředí, kulturní dědictví a hospodářskou činnost, které souvisejí s povodněmi. Podle požadavků této směrnice jsou pořizovány Plány pro zvládání povodňových rizik (dále jen PpZPR).

Významné věcné vstupy pro prípravu druhého plánovacího období představovaly i tzv. implementační zprávy Evropské komise. V souladu s článkem 18 Rámcové směrnice o vodě bylo povinností Evropské komise zveřejnit zprávu Evropskému parlamentu a Radě o provádění této směrnice, a to nejpozději do 22. prosince 2012 ( $v$ pořadí šlo celkem již o třetí implementační zprávu). Tato zpráva zahrnovala mj. přezkoumání pokroku při implementaci směrnice a hodnocení plánů povodí předložených v souladu s článkem 15 včetně doporučení pro zlepšení budoucích plánů.

Tato zpráva byla prijiata dne 14. listopadu 2012 a skládala se ze samotné Zprávy komise Evropskému parlamentu a Radě o provádění Rámcové směrnice o vodě plány povodí COM (2012) 670, dále z pracovního dokumentu komise (tzv. European Overview) a z posouzení plánů povodí specifického pro jednotlivé země.

V kontextu této zprávy a navazujících aktivit Evropské komise ke zvýšení kvality návrhu plánů povodí pro druhý plánovací cyklus se dne 29. ledna 2014 uskutečnilo bilaterální jednání zástupců ČR a Evropské komise v Bruselu. Výsledkem tohoto jednání bylo vymezení problémových aspektů vyplývajících z prvního plánovacího cyklu a stanovení konkrétních kroků (tzv. actions) k jejich nápravě.

Prozatím poslední implementační zpráva Evropské komise (v pořadí čtvrtá), přijatá dne 9. března 2015, zahrnovala posouzení pokroku při provádění programů opatření navržených členskými státy v plánech povodí pro první plánovací cyklus. Průběžná zpráva byla založena na analýze zpráv předložených členskými státy v souladu s článkem 15.3 a obsahovala také návrhy na zlepšení programů opatření, která měla být zařazena do aktualizace plánů povodí pro druhý plánovací cyklus.

Pro zajištění koordinace přípravy jednotlivých národních plánů povodí, dílčích plánů povodí a plánů pro zvládání povodňových rizik byla, obdobně jako pro prípravu plánů povodí pro první plánovací období, Ministerstvem zemědělství a Ministerstvem životního prostředízřizena Komise pro plánování v oblasti vod. Členy této skupiny byli zástupci ústředních správních úřadů, do jejichž působnosti spadají jednotlivé oblasti mající vztah k plánování v oblasti vod, krajských úřadů, Asociace krajů ČR, správců povodí, Lesy ČR, státních podniků, významných vodohospodáŕských institucí, Agentury ochrany prírody a krajiny, České inspekce životního prostředí, významných uživatelů vod i nevládních organizací. Do Komise pro plánování v oblasti vod byla začleněna i pracovní skupina pro implementaci Povodňové směrnice, která byla založena Ministerstvem životního prostředí v roce 2008. 
Koordinace na mezinárodní úrovni je zajištěna zapojením ČR v rámci činnosti mezinárodních komisí v jednotlivých mezinárodních povodích.

Práce na aktualizaci plánů povodí pro druhý plánovací cyklus probíhaly v období 2011-2015. V rámci prípravných prací byly přezkoumány a aktualizovány cíle a programy opatření $k$ jejich naplnění. Na základě nové typologie povrchových vod došlo rovněž k významnému převymezení útvarů povrchových vod, dále byly změněny hodnoty ( $\vee \vee$ některých prípadech i ukazatele) velmi dobrého, dobrého a středního stavu všeobecných fyzikálně-chemických složek ekologického stavu/potenciálu a změnil se i rozsah a kvalita monitorovaných dat. Počet sledovaných měrných profilů a vodních útvarů se zvětšil a významně narostl rozsah sledování biologických složek. Proto bylo možno ve druhém plánovacím období na základě dat z monitoringu hodnotit i ty vodní útvary, jejichž stav musel být v prvním plánovacím období hodnocen jinými postupy, nebo na základě expertního odhadu.

Od doby vypracování plánů povodí pro první plánovací cyklus v roce 2009 došlo $v$ různých kategoriích povrchových vod téměř pro všechny složky biologické kvality k metodickým úpravám postupů hodnocení. Změn doznal i postup identifikace silně ovlivněných vodních útvarů (hlavně tekoucích vod) a metody hodnocení ekologického potenciálu.

$\checkmark$ prípadě chemického stavu útvarů povrchových vod došlo na evropské úrovni ke změnám limitů dobrého stavu pro část ukazatelů, popř. ke změně matrice. Pro účely hodnocení chemického stavu útvarů podzemních vod vzrostl počet hodnocených ukazatelů a oproti prvnímu plánovacímu období byly více zohledněny další receptory, s čímž souvisí zprísnění limitů dobrého stavu. Stejně jako u povrchových vod byl významně zlepšen monitoring, a to jak z hlediska zvýšení počtu monitorovacích míst, tak z hlediska sledování dalších ukazatelů.

Př́prava aktualizace plánů povodí formálně vyvrcholila schválením NPP vládou České republiky dne 21. prosince 2015. V souladu s vodním zákonem byly NPP následně vydány Ministerstvem zemědělství jako opatření obecné povahy, které nabylo účinnosti 28. ledna 2016.

PpZPR byly schváleny vládou České republiky dne 21. prosince 2015. V souladu s vodním zákonem byly PpZPR následně vydány Ministerstvem životního prostředí jako opatření obecné povahy, které vstoupilo v platnost 19. ledna 2016.

Jednotlivé PDP byly postupně schváleny v první polovině roku 2016 jednotlivými kraji podle jejich územní působnosti.

NPP, PpZPR i PDP procházely rovněž společným posouzením vlivu koncepce na životní prostředí (SEA) v souladu se zákonem č. 100/2001 Sb., o posuzování vlivů na životní prostředí, ve znění pozdějších předpisů.

Dnem schválení plánů pro druhou etapu procesu plánování v oblasti vod započala realizace programu opatření, které tyto plány přijaly. Realizaci opatření je nutno uskutečnit do 3 let od schválení plánů, tj. do 22. prosince 2018. O prrijetí plánů povodí byla v roce 2016 podána zpráva Evropské komisi v souladu s článkem 15 směrnice.

V mezinárodním kontextu byly i ve druhém plánovacím období vzájemně koordinovány kroky k provádění požadavků Rámcové směrnice o vodách $\checkmark$ ucelených povodích řek Labe, Odry a Dunaje. I na úrovni mezinárodních komisí MKOL, MKOOpZ a MKOD bylo zohledněno nabytí účinnosti Směrnice Evropského parlamentu a Rady 2007/60/ES o vyhodnocování a zvládání povodňových rizik, kdy v rámci prrípravných prací procesu plánování v oblasti vod byly zahájeny koordinované práce na zpracování mezinárodních plánů pro zvládání povodňových rizik. Koordinace činností v prípravě tohoto plánovacího období $\checkmark$ mezinárodních povodích byly úspěšně zakončeny schválením aktualizovaných mezinárodních plánů povodí a prvních mezinárodních plánů pro zvládání povodňových rizik. Jednotlivé mezinárodní komise a jejich pracovní a expertní skupiny představují rovněž vhodnou platformu pro sdílení zkušeností národních expertů a vytváření koordinovaného př́stupů při naplňování požadavků Rámcové směrnice o vodách a Povodňové směrnice v ucelených povodích.

\section{DALŠÍ KROKY V PROCESU PLÁNOVÁNÍ V OBLASTI VOD}

I přes fakt, že Rámcová směrnice o vodách je v platnosti již více než patnáct let a členské státy vynakládají značné úsilí pro naplňování jejich cílů, zůstává i pro třetí plánovací období celá řada zásadních výzev.

Společný úkol pro Ministerstvo zemědělství, Ministerstvo životního prostředí, správce povodí a krajské úřady představuje $v$ nadcházejícím období zajištování implementace programu opatření navrženého v druhém plánovacím období a zároveň i príprava aktualizace plánů povodí a plánů pro zvládání povodňových rizik na období 2022-2027. Uvedené plány musí být připraveny a schváleny vládou ČR do 22. prosince 2021. S ohledem na skutečnost, že platné znění Rámcové směrnice o vodách neumožňuje nyní prodlužování lhůt pro dosažení dobrého stavu za rok 2027, jedná se tak de facto o poslední aktualizaci plánů. Je proto nutné věnovat prípravě plánů mimořádnou pozornost a společným úsilím všech zainteresovaných stran zajistit všechny činnosti vedoucí ke zlepšení stavu vod do roku 2027.

$\checkmark$ tomto kontextu je vhodné závěrem zmínit i aktivitu EK $v$ podobě připravovaného přezkoumání Rámcové směrnice o vodách, vyplývající z článku 19 odst. 2 této směrnice. Výstupem tohoto přezkoumání by měl být návrh změn, které budou dále určovat rámcové směřování ochrany vod a vodní politiky na úrovni EU po roce 2027.

\section{Autoři}

RNDr. Jakub Čurda

凶jakub.curda@mzp.cz

Ing. Jaroslav Kinkor

凶jaroslav.kinkor@mzp.cz

Ministerstvo životního prostředí

\section{BASES AND HISTORICAL CONTEXT OF THE PLANNING PROCESS IN THE FIELD OF WATER}

\section{CURDA, J.; KINKOR, J.}

Ministry of Environment of the Czech Republic

Keywords: planning - Water Framework Directive -

Floods Directive - European Union

Water planning is a systematic conceptual activity which implements the requirements of the Water Framework Directive. The main objective of the Water Framework Directive is to prevent any further deterioration of surface waters and groundwater and the improve the condition of the waters and water dependent ecosystems. The main purpose of the following text is to provide a brief summary of the historical background and current starting-point of the water planning process. 